\title{
Preparation of Coconut Milk as Dandruff Removal
}

\author{
Marini Damanik*, Hafni Indriati Nasution, Rini Selly, Moondra Zubir \\ Chemistry Department, Faculty of Mathematics and natural Sciences, Universitas Negeri Medan, Medan, 20371, \\ Sumatera Utara \\ *Email : marini@unimed.ac.id
}

\begin{abstract}
Coconut milk is a thick white liquid extracted from coconut produced from shredded coconut and then squeezed with water. Coconut milk is an ingredient produced from processed old coconut. Coconut milk can be used as food preparations or as herbal beauty ingredients. One of the advantages of coconut milk in the field of beauty is that it is very effective as a dandruff remover. By using old coconut milk as a dandruff remover we can get amazing results with natural ingredients without spending a lot of money. Coconut milk has many contents such as water content, protein and fat which are quite high as well as cow's milk. Coconut milk is rich in vitamins $C$, $B, B-6$, thiamine, niacin, folate, a number of minerals (calcium, magnesium, iron and phosphorus). Pure coconut milk only contains 54 percent water, 35 percent fat and 11 percent nonfat solids (approximately 6 percent carbohydrates, less than 4 percent protein and other solids) which are categorized as emulsions of oil in water. Coconut milk is known to be effective in eliminating dandruff, because coconut milk contains coconut oil containing Vitramin $E$ and fatty acids that can eliminate and eradicate dandruff. You do this by using coconut oil as a massage oil to massage the scalp.
\end{abstract}

Keywords: coconut milk, coconut oil, dandruff removal.

\section{Pendahuluan}

Pada zaman modern ini banyak terdapat berbagai jenis cosmetic dipasaran, cosmetic yang berfungsi menghilangkan ketombe di kepala juga banyak dijual di pasaran dengan harga yangberfungsi menghilangkan ketombe di kepala juga banyak dijual di pasaran dengan harga yang bermacam macam. Semua cosmetic pembasmi ketombe yang ada diasaran sudah tercampur dengan berbagai bahan kimia, itu dapat menyebabkan banyak resiko terhadap kepala kita, seperti bukannya menghilangkan ketombe tapi membuat rambut kita rontok, atau sebagainya. Tapi tidak usah takut dan khawatir sekarang kita akan memberi tahu tentang cosmetic herbal yang alami, murah, mudah didapat dan pastinya bias dibuat di rumah masing-masing. Produk cosmetic itu adalah santan kelapa. ${ }^{1}$
SANTAN KELAPA atau 'Coconut Milk' merupakan satu produk dari biji kelapa (Cocos nucifera) yang banyak kegunaannya. Santan Kelapa dihasilkan dari perahan isi kelapa yaitu cairan yang berwarna putih serta mengandungi banyak zat makanan. Pada zaman dahulu, secara tradisional isi kelapa akan diparut dengan menggunakan alatan 'Parut' atau 'Kukur' kemudian dicampur dengan air sebelum diperah bagi menghasilkan santan. ${ }^{2}$ Pada masa kini santan kelapa dapat diperah terus secara cekap menggunakan Alatan Mesin Pemerah Santan Kelapa. Terdapat beberapa varieti kelapa yang mengandungi santan yang banyak dan ada juga varieti kelapa yang kurang kandungan santannya. Umur pokok juga memainkan peranan penting mengenai kualiti santan dimana pokok muda kualiti 
santanya rendah (cair) berbanding dengan pokok tua. Lazimnya biji kelapa dari pokok yang tua memberikan kualiti santan lebih baik kerana ianya lebih pekat. ${ }^{3}$

Santan Kelapa banyak mengandungi zat permakanan seperti Vitamin, Lemak, Asid Laurik serta banyak kandungan mineral (Kalsiam dan Ferum). Setiap 15 gram santan mengandungi sebanyak 35 kilokalori tenaga, Lemak (3.6 g atau 6\% dimana 3.2 gram adalah Lemak Tepu dan sebanyak 0.2 gram adalah Lemak Tidak Tepu), Protin (0.3 gram), Gula (0.2 gram), Serat (0.2 gram) dan Karbohiderat (0.8 gram) serta Vitamin A dan Vitamin C. ${ }^{4}$ Kandungan zat dalam permakanan ini banyak bergantung kepada varieti kelapa dan umur pokok kelapa. Kandungan air dalam santan kelapa adalah komponen paling tinggi..Makalah ini akan memberi informasi tentang kandungan santan yang dipercaya ampuh dapat menghilangkan ketombe di kepala dan juga cara menggunakan santan kelapa untuk menghilangkan ketombe dengan praktis dan cepat.

\section{Metodologi Penelitian}

\subsection{Bahan yang Digunakan}

Bahan yang digunakan untuk membuat santan pasta terdiri atas kelapa (kelapa setengah tua dengan ciri warna kulit ari berwarna coklat kemerahan bukan coklat kehitaman) Dan air hangat. Alat -alat yang digunakan untuk mini riset ini adalah pisau/parang yang akan digunakan untuk membelah kelapa, alat pemotong kelapa, kain penyaring/saringan, gelas untuk mengukur jumlah air yang akan digunakan, wadah berusapa mangkuk/baskom, dan botol shampoo yang sudah tidak terpakai.

\subsection{Teknik Pengumpulan Data}

Teknik pengumpulan data yang digunakan dalam proses mini riset ini ini adalah melalui riset dari berbagai sumber. Penulis melakukan telaah tinjauan pustaka yang berupa buku-buku teks, artikel-artikel di internet, dan sumber-sumber lain yang berkaitan dengan rumusan masalah yang akan dibahas.

\subsection{Analisis Data}

Data yang diperoleh dalam penelitian ini yang kemudian diolah dan dianalisis secara kuantitatif agar dapat menjawab dari batasan rumusan masalah karya tulis ilmiah mengenai pemanfaatan santan kelapa sebagai alternatif obat untuk menghilangkan ketombe.

\subsection{Pembuatan Kosmetik dari Santan}

Langkah pertama kupas sambuk dan batok kelapa. Kemudian kelapa yang sudah dikupas dari kulitnya kemudian dicuci hingga bersih. Langkah ketiga parut kelapa dengan parutan kelapa hingga semua menjadi ampas-ampas kelapa. Pindahkan kelapa yang telah diparut kedalam wadah/mangkuk. Langkah keempat yaitu tambahkan air hangat ke baskom tempat ampas kelapa. Kemudian peras-peras ampas kelapa hingga sari kelapa keluar. Langkah keenam yaitu saring ampas kelapa dengan penyaringan hingga yang tersisa hanya air sari-sari kelapa. Santan sederhana yang mempunyai banyak manfaat pun sudah jadi. Langkah terakhir yaitu penggunaan santan kelapa di rambut, agar mudah untuk digunakan dalam kehidupan sehari-hari gunakan botol kecil untuk wadah, Gunakan santan tersebut setelah dibuat (langsung) sebelum basi dan tidak bermanfaat.Gunakan santan tersebut 3 sampai 4 kali seminggu agar hasil lebih maksimal.

\section{Hasil dan Diskusi}

Hasil penelitian adalah santan yang sudah siap digunakan, akan diuji tes dikepala seorang penderita penyakit ketombe. Kami menyarankan kepada penderita ketombe tersebut untuk memakai bahan dari santan kelapa secara rutin dan teratur. Pada hari pertama penderita ketombe belum merasakan adanya perubahan pada ketombe yang dideritanya. (Tabel 1)

Berjalan 2-3 hari terlihat adanya perubahan terhadap ketombe di kulit kepala penderita ketombe, ketombenya berkurang sekitar $5 \%$ dan peneliti menganjurkan kepada penderita ketombe untuk terus memakai shampo ini, Setelah berjalan 4- 5 hari. Ketombe yang diderita oleh penderita ketombe mulai mengalami pengurangan ketombe sekitar $20 \%$. Melihat perkembangan yang mulai nampak jalan keluarnya untuk mengatasi ketombe yang diderita penderita tersebut, peneliti terus menyarankan agar penderita ketombe terus menggunakan shampo kulit nanas tersebut secara rutin. Berjalan pada hari ke 6 mengalami pengurangan ketombe hingga $30 \%$. 
Tabel 1. Pengaruh Santan Kelapa Menghilangkan Ketombe.

\begin{tabular}{|c|c|c|l|c|}
\hline No & $\begin{array}{c}\text { Minggu } \\
\text { Ke - }\end{array}$ & Hari ke- & $\begin{array}{l}\text { Pengaruh santan } \\
\text { Kelapa Terhadap } \\
\text { penderita ketombe }\end{array}$ & Persen \\
\hline 1. & 1 & 1 & $\begin{array}{l}\text { Penderita ketombe } \\
\text { belum merasakan } \\
\text { adanya perubahan } \\
\text { Terlihat adanya } \\
\text { perubahan } \\
\text { terhadap ketombe } \\
\text { di kulit kepala } \\
\text { penderita ketombe }\end{array}$ & 0 \\
\hline 2. & 1 & 4,5 & $\begin{array}{l}\text { Ketombe mulai } \\
\text { berkurang. Karena } \\
\text { mulai ada } \\
\text { pengaruh dari } \\
\text { shampo alternatif } \\
\text { ini }\end{array}$ & 5 \\
\hline 3. & 2 & 6 & $\begin{array}{l}\text { Berkurangnya } \\
\text { ketombe di kulit } \\
\text { kepala penderita } \\
\text { ketombe }\end{array}$ & 20 \\
\hline 5. & 2 & 8 & $\begin{array}{l}\text { Terus } \\
\text { berkurangnya } \\
\text { ketombe di kulit } \\
\text { kepala penderita } \\
\text { ketombe }\end{array}$ & $\begin{array}{l}\text { Ketombe telah } \\
\text { berkurang dan } \\
\text { hilang. }\end{array}$ \\
\hline 4. & 2,30 \\
\hline
\end{tabular}

Sedangkan 7 hari ketombe yang diderita penderita pun mulai berkurang, pengurangan ketombe pada kulit kepala si penderita berkurang hingga $50 \%$. Melihat perkembangan yang luar biasa tersebut peneliti terus menganjurkan penderita ketombe agar terus memakai shampo tersebut. Selanjutnya, pada hari berikutnya hari ke 8 , peneliti pun melihat perkembangan yang terjadi pada kulit kepala penderita ketombe, ternyata ketombe yang diderita oleh penderita ketombe berkurang hingga 90\%. Uraian tersebut, merupakan hasil penelitian yang dilakukan pada sampel pemakaian santan kelapa selama 3 atau 4 kali dalam seminggu (sekali pemakaian santan kelapa dilakukan satu kali dalam sehari). Penelitian pada sampel ini menunjukan hasil yang jauh lebih efektif untuk menghilangkan ketombe dibandingkan dengan sampel penelitian yang lain.

Penelitian yang lain adalah pemakaian shampo berturut-turut selama seminggu karena kulit kepala dan jenis rambut manusia memiliki perbedaan tingkat sensitivitas dalam pemakaian shampo. Ada yang memiliki tingkat sensitivitas tinggi dan ada yang memiliki tingkat sensitivitas rendah terhadap pemakaian shampo. Berdasarkan hasil pengamatan di atas, santan kelapa dapat menciptakan sebuah obat alami yang bermanfaat untuk menghilangkan ketombe di kulit kepala penderita ketombe. Akan tetapi, yang harus diperhatikan supaya hasilnya lebih maksimal adalah memakai obat alternative tetapi, yang harus diperhatikan supaya hasilnya lebih maksimal adalah memakai obat alternatif dari santan kelapa harus teratur dan rutin menggunakan shampo tersebut 3 sampai 4 kali seminggu.

\section{Kesimpulan}

Berdasarkan pembahasan hasil penelitian di atas, maka dapat disimpulkan beberapa hal sebagai berikut :

1. Proses pembuatan alternatif obat dari santan kelapa sebenarnya sangat mudah hanya saja membutuhkanketelatenan dan ketelitian. Proses pembuatanya adalah dengan cara memarut, memeras lalu menyaring ampas kelapanya. Kemudian santan itu sudah siap digunakan tanpa dicampur bahan lain.

2. Ternyata pengaruh shampo santan kelapa ini dapat menghilangkan ketombe. Akan tetapi, yang harus diperhatikan supaya hasilnya lebih maksimal adalah memakai shampo alternatif dari santan kelapa harus teratur dan rutin menggunakan shampo tersebut 3 sampai 4 kali seminggu.

\section{Referensi}

1. Winarno FG. 2004. Kimia pangan dan gizi. Gramedia Pustaka Utama. Jakarta.

2. Palungkun R. 2004. Aneka produk olahan kelapa. Penebar Swadaya. Jakarta.

3. Effect of thermal treatments on the properties of coconut milk emulsions prepared with surfaceactive stabilizers (www.elsevier.com/locate/foodhyd)

4. Pengaruh Penambahan Emulsifier dan Stabilizer Terhadap Kualitas Santan Kelapa (http://ejournal.unsrat.ac.id/index.php/jmu) 